\title{
Other Military Specific Workers
}

National Cancer Institute

\section{Source}

National Cancer Institute. Other Military Specific Workers. NCI Thesaurus. Code C122550.

Military specific workers not specifically identified elsewhere. 